\title{
STUDY OF THE INFLUENCE OF SYSTEMIC FACTORS ON THE LEVEL OF LAND USE OF THE REGIONAL NATURE RESERVE FUND
}

\author{
Konstantin Viatkin ${ }^{1}$, Roman Viatkin ${ }^{2}$ \\ ${ }^{1}$ Department of Urban construction, O. M. Beketov National University of Urban Economy in Kharkiv, Kharkiv, Ukraine \\ vyatkin.k.i@gmail.com \\ ORCID: http://orcid.org/0000-0002-3002-5669 \\ ${ }^{2}$ Department of Land administration and geographic information systems, O. M. Beketov National University of Urban Economy in \\ Kharkiv, Kharkiv, Ukraine \\ viatkinr@gmail.com \\ ORCID: http://orcid.org/0000-0001-8807-9988
}

\begin{tabular}{l} 
A R T ICLE IN F O \\
Article history: \\
Received date 10.09 .2020 \\
Accepted date 19.10 .2020 \\
Published date 30.10 .2020 \\
Section: \\
Information Technology \\
D O I \\
\hline $10.21303 / 2313-8416.2020 .001495$
\end{tabular}

KEYWORDS

land use

objects of natural reserve fund

mathematical modeling

integral indicator

method of neural networks

system factor

\section{A B S T R AC T}

An urgent issue is the determination of the functional purpose and increasing the efficiency of using the lands of the natural reserve fund.

The object of research: lands of the natural reserve fund.

Investigated problem. According to the legal framework, which was used in the study, it was determined certain aspects of their functioning in the context of environmental protection measures. The processes of using the lands of the natural reserve fund should be considered as a complex process; therefore, the influence of systemic factors on the level of use of the lands of the natural reserve fund of the regions is studied. To carry out the analysis, methods of mathematical modeling were used as a mechanism for coordinating the influence of a set of indicators and determining their relationships.

Main scientific results. The results of mathematical modeling have been obtained, which provide an opportunity to predict changes in the integral indicator of the level of land use of objects of the natural reserve fund of regions, depending on the relevant factors, and to offer scientifically substantiated recommendations for the development and implementation of monitoring of the formation of lands of objects of the natural reserve fund of regions. The integral indicator was developed on the basis of the analysis and assessment of a set of factors that are defined as parameters for assessing the lands of the natural reserve fund. The analysis of the adequacy of the developed mathematical models of the influence of factors on the integral indicator of the level of land use of objects of the natural reserve fund of the regions using the neural network method made it possible to confirm the completeness and reliability of the established relationships based on low values of the relative error of the test sample.

The area of practical use of research results. Thus, the practical significance of the developed model for the formation of a methodology for assessing the processes of using lands of the natural reserve fund has been determined.

Innovative technological product: an integral model for assessing the lands of the natural reserve fund.

Scope of application of an innovative technological product. This technique makes it possible to increase the efficiency and rationalize the processes of using the lands of the natural reserve fund in order to protect them and ensure integrated functioning.

(C) The Author(s) 2020. This is an open access article under the CC BY license http://creativecommons.org/licenses/by/4.0).

\section{Introduction}

\section{1. The object of research}

The object of research is the lands of the nature reserve fund. The formation of land use directions at the regional level, their impact on the livelihoods of the population depends on the creation and use of objects of the natural reserve fund, taking into account environmental factors. At the present stage, the tasks of developing the lands of the objects of the natural reserve fund of the regions have not been solved, a system of information-analytical and spatial support for their determination has not been built, and the level of efficiency of their use is reduced. In such conditions, it becomes necessary to monitor the use of lands of objects of the natural reserve fund on the basis of information and analytical support, using the tools of geoinformation systems. 


\section{2. Problem description}

In modern conditions, the formation of areas of land use, their protection and rational use is of particular importance. In recent years, the influence of anthropogenic factors on all natural processes, including land resources, has been growing. Irrational use of lands leads to their degradation, which is caused by excessive plowing, limited use of organic and mineral fertilizers, insufficient protection of soils by agroforestry measures and low quality of soil use technologies. Rational use and protection of lands is a scientifically based process that takes into account the natural properties of lands for their intended purpose, while observing the directions of their protection. To solve the presented tasks, it is proposed to monitor land use based on the formation and use of information and analytical support.

\section{3. Suggested solution to the problem}

The rational use and protection of lands of the natural reserve fund is an important scientific, theoretical and practical task. The processes of using the lands of the natural reserve fund should be considered as a complex process; therefore, the influence of systemic factors on the level of use of the lands of the natural reserve fund of the regions is studied. The methodology developed in the article makes it possible to increase the efficiency and rationalize the processes of using the lands of the natural reserve fund in order to protect them and ensure integrated functioning.

Characterizing the theoretical provisions for determining the influence of systemic factors on the use of lands of objects of the natural reserve fund, it should be noted that there are no unified approaches to its substantiation. Special attention should be paid to the legal approach to determining the influence of systemic factors on the use of lands of objects of the natural reserve fund. In their scientific developments, the authors [1-3] investigated the influence of the legal regime on the use and monitoring of protected lands in Ukraine. Special attention should be paid to a constructive approach to the definition of monitoring of lands of objects of the natural reserve fund, within the framework of which the authors $[4,5]$ determine the structural elements of the eco-network of Ukraine, comparing it with international analogues.

Special mention should be made of the opinion of the authors [6, 7], who point to the need to create a perfect system for monitoring the influence of systemic factors on the ground of objects of the natural reserve fund. At the same time, in work [8], the author highlights certain technologies for its creation and implementation.

The analysis of existing theoretical approaches to determining the influence of systemic factors on the ground of objects of the natural reserve fund, which showed their fragmentation and the lack of uniform provisions. It should be noted that in the existing scientific developments in the system of influence on the land use of the objects of the natural reserve fund of the regions, the tools for its development and implementation are not taken into account $[9,10,12]$. They are based on the complex application of modern instrumental base, in particular, geodetic, geoinformation systems, space survey results, modern specialized software [9, 11].

So, the presented studies require a thorough study and systematization of scientific provisions with the subsequent development of recommendations on the impact of systemic factors on the use of lands of the natural reserve fund of the regions.

The aim of research. To determine the influence of systemic factors on the level of use of lands of the natural reserve fund by developing information and analytical support for the formation and implementation of monitoring of lands of objects of the natural reserve fund of regions using methods of mathematical modeling.

\section{Materials and methods}

The development of information and analytical support for monitoring the land use of objects of the natural reserve fund of the regions is carried out on the basis of mathematical modeling of the influence of system factors on the integral indicator of the level of land use.

Mathematical modeling of the influence of systemic factors on the integral indicator of the level of land use of objects of the natural reserve fund of regions is carried out in accordance with the developed stages. As a result of the research: 
- a mathematical model that determines the degree of impact of the systemic factor in the development of information and analytical support for the formation and implementation of monitoring of lands of objects of the natural reserve fund of regions $\left(E L_{2}\right)$ on the integral indicator of the level of land use of objects of the natural reserve fund of regions $\left(I_{E L}\right)$ (Fig. 1);

- mathematical model, determines the degree of impact of the system factor of the level of rational use and protection of natural resources, the factors influencing the development of monitoring the formation of lands of objects of the natural reserve fund of regions $\left(E L_{3}\right)$ on the integral indicator of the level of land use of objects of the natural reserve fund of regions $\left(I_{E L}\right)$, c.u. (Fig. 2).

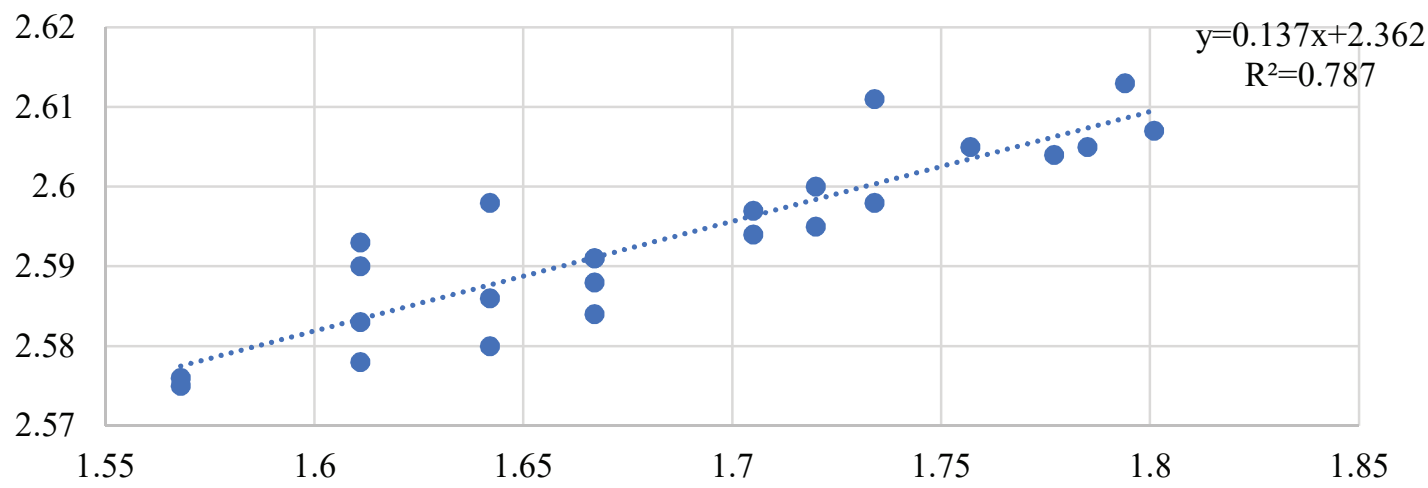

Fig. 1. The mathematical model determines the degree of impact of the systemic factor in the development of information and analytical support for the formation and implementation of land monitoring of NRF facilities in regions $\left(E L_{2}\right)$ on the integral indicator of the level of land use at NRF facilities in regions (I_EL), rel. unit

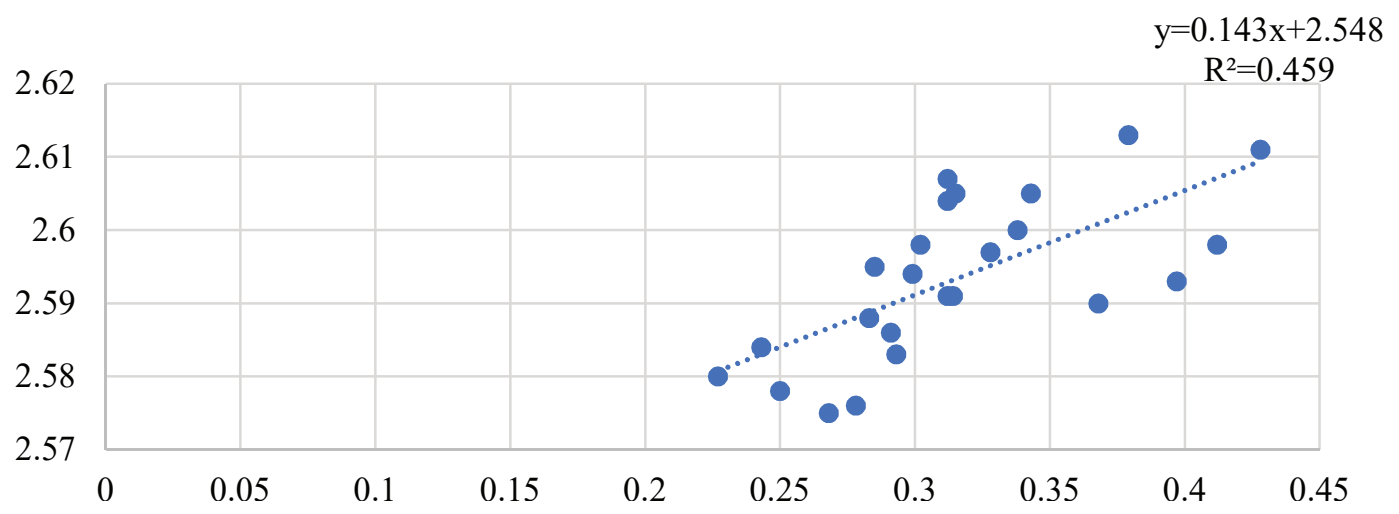

Fig. 2. The mathematical model determines the degree of influence of the systemic factor of the level of rational use and protection of natural resources, influencing the development of monitoring the formation of land in NRF facilities in regions $\left(E L_{3}\right)$ on the integral indicator of the level of land use in NRF facilities in regions (I_EL), c. u.

As a result of mathematical modeling, it was found that changes in the system factor for the development of information and analytical support for the formation and implementation of monitoring of lands of objects of the natural reserve fund of regions $\left(E L_{2}\right)$ by $78.7 \%$ causes changes in the integral indicator of the level of land use of objects of the natural reserve fund of regions $\left(I_{E L}\right)$. This indicates a high level of influence of information and analytical support and requires the development of appropriate scientifically grounded measures for their growth.

A change in the systemic factor of the level of rational use and protection of natural resources, influencing the development of monitoring the formation of lands of objects of the natural reserve fund of regions $\left(E L_{3}\right)$ by $45.9 \%$, causes changes in the integral indicator of the level of use of lands of objects of the natural reserve fund of regions $\left(I_{E L}\right)$. This is a profound meaning, indicating the need to take action to increase the direction of implementation of the rational use and protection of natural resources. 


\section{Results}

The results of mathematical modeling provide an opportunity to predict changes in the integral indicator of the level of land use in the objects of the natural reserve fund of the regions, depending on the relevant factors and to offer scientifically grounded recommendations for the development and implementation of monitoring of the formation of lands of the objects of the natural reserve fund of the regions.

To confirm the adequacy of the established links between the integral indicator of the level of land use of objects of the natural reserve fund of regions and factors, the method of neural networks is used based on the STATISTICA Neural Networks software package. Neural networks allow to model and reproduce complex nonlinear dependencies, while simultaneously requiring a lower level of knowledge than when using traditional statistical methods.

The study involves solving a regression problem. As the initial data, let's take the indicators $E L_{2}, E L_{3}$, which act as independent predictors and affect the final result. The dependent variable is the $I_{E L}$ indicator (Fig. 3). The neural network will work with two input elements and one output variable. The sample was formed on the basis of available data for all regions of the country.

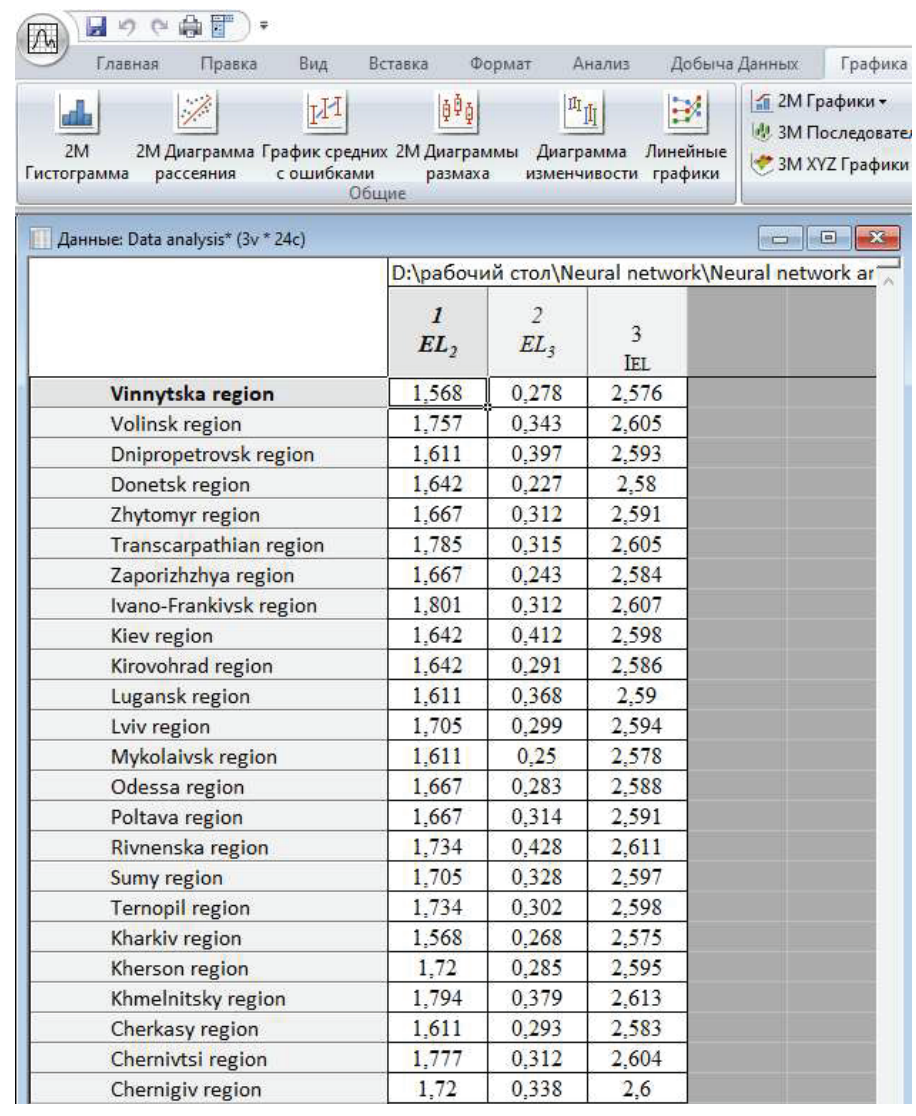

Fig. 3. Formation of a data sample for regression analysis, c.u.

Let's construct a neuromechanical model for the presented data using the Automated Neural Networks package of automated neural networks and data analysis Regression. Let's select the necessary variables for analysis: continuous target and continuous input (Fig. 4).

At this stage, the strategy for creating a network model is determined, the sizes of the learning, control and test subsamples are established, and the like. Choosing an automated neural network requires a minimum amount of settings. The network architecture is based on the multilayer perceptron (MLP). This type of network is adopted as a model for regression analysis of indicators of territorial development of land use in the region. The main advantages of MLP, namely ease of use and the necessary generalizing properties, ensure its widespread use. Each network element builds a weighted sum of its inputs, corrected as a term, and passes this activation value through the transfer function, having received the initial value of this element. The elements are organized in a 
layered topology with direct signal transmission. This type of network is based on the input-output model, in which the weights and threshold values are the free parameters of the model [12].

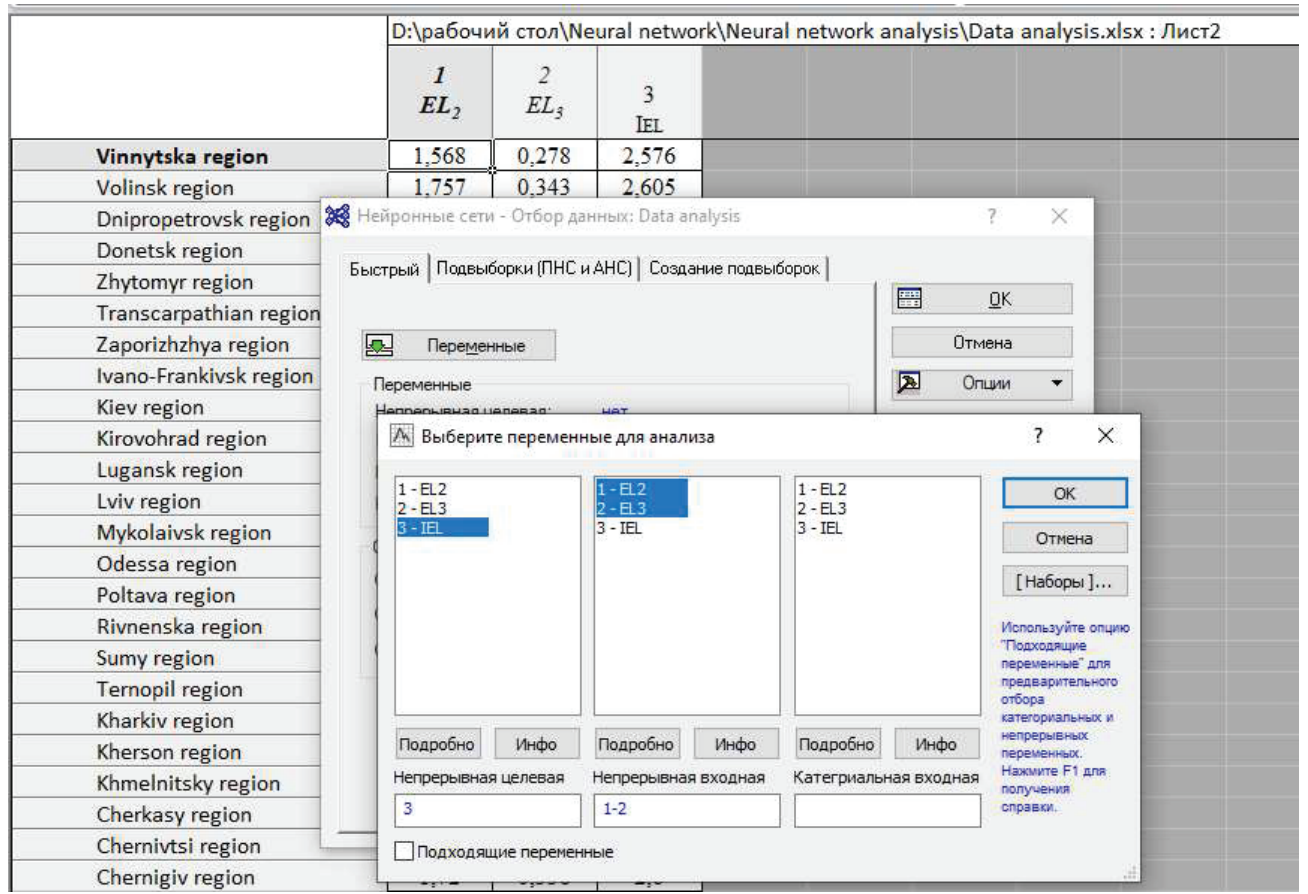

Fig. 4. Selecting variables for analysis

When designing MLP, an important process is determining the number of intermediate layers and the number of elements in them. Let's accept the minimum value of the number of hidden neurons as a half-sum of input and output elements. In our case, the minimum value will be 2 , and the maximum number of hidden neurons will be set at 10 (Fig. 5).

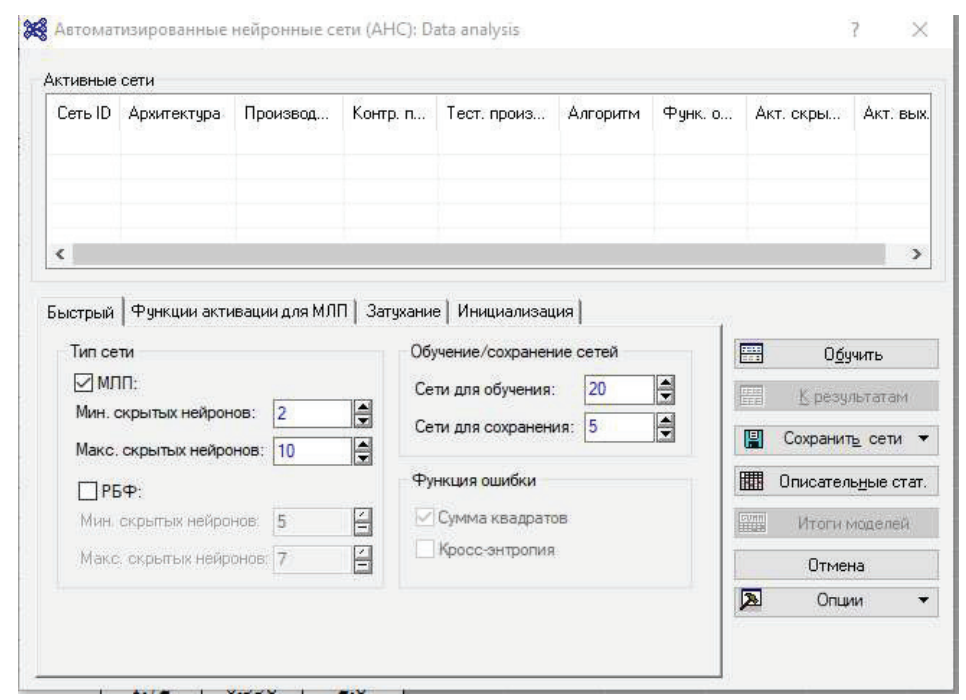

Fig. 5. Choice of settings for building a network with multilayer perceptron (MLP) architecture

The initial value of the multilayer perceptron is calculated by the formula:

$$
y=F\left(\sum_{j=1}^{n} \vartheta_{j} h_{j}-b\right),
$$


where $n$ - the number of neurons in the hidden layer;

$\vartheta_{j}$ - the weight of the synapse of the neuron $\mathrm{j}$ of the hidden layer to the original neuron;

$h_{j}$ - the initial value of the neuron $\mathrm{j}$ of the hidden layer;

$b$ - the threshold of the output neuron;

$F$ - activation function of the output neuron.

For each layer of the neural network, let's define the activation functions of the neural network - functions that convert the level of neuron activation into an output signal. Let's consider the hyperbolic tangent as the activation function of the hidden layer:

$$
f(x)=\frac{2}{1+e^{-2 x}}-1
$$

The hyperbolic tangent at the input takes an arbitrary real number, at the output it gives a number in the interval $(-1 ; 1)$. The hyperbolic tangent can saturate, and the output of this function is centered relative to zero, which in practice expands the possibilities of its use.

The value of the neuron of the hidden layer at the output is determined by the formula:

$$
h_{j}=F_{2}\left(\sum_{i=1}^{m} w_{i j} x_{i}-b_{2 j}\right) \text {, }
$$

where $w_{i j}$ - the weight from the $j$-th neuron at the input to the $j$-th neuron of the hidden layer;

$x_{i}$ - input value;

$b_{2 j}$ - the value of the threshold of the first neuron of the hidden layer;

$F_{2}$ - hidden layer activation function.

In the neural network model chosen in the study with the highest performance, the activation function of the output layer also has a hyperbolic tangent with a range of values in the interval $(-1 ; 1)$.

Let's carry out the process of learning networks (Fig. 6).

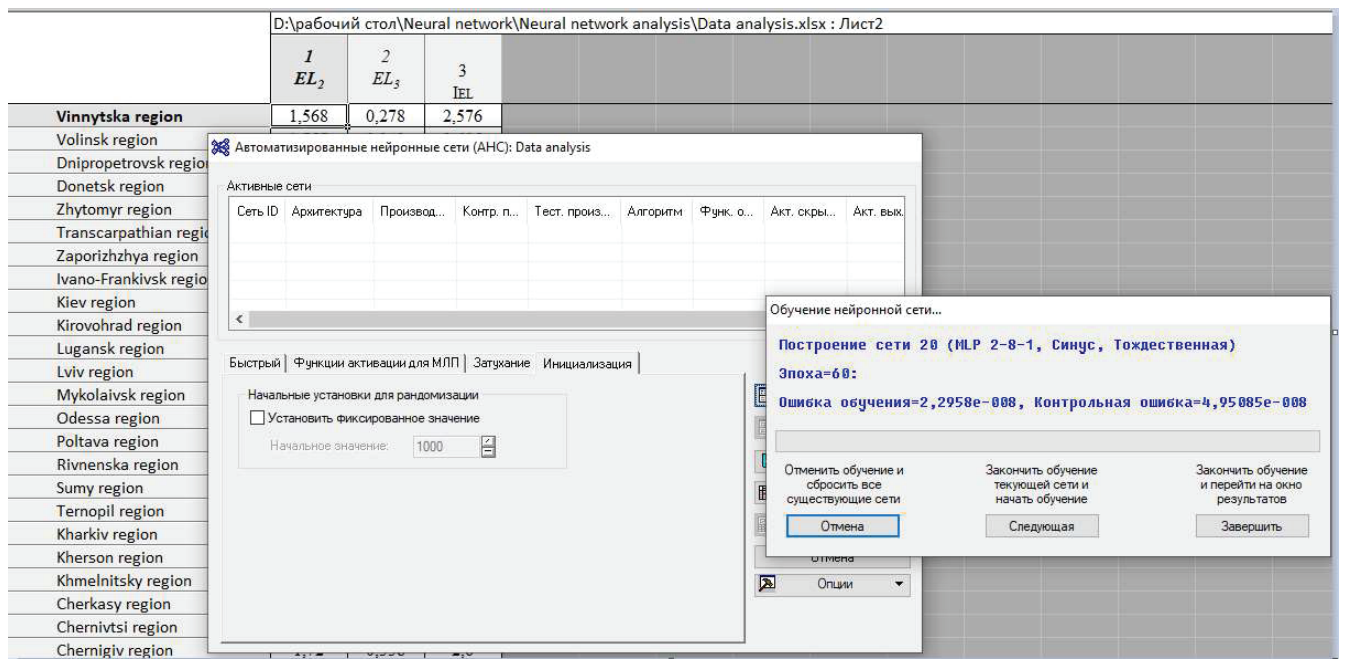

Fig. 6. The process of learning a neural network, c.u.

The dialog box provides information for learning the network, namely the network ID, its architecture and activation functions for the hidden and incoming layers, the number of algorithm iterations and learning errors. As learning outcomes, have the best neural networks that were selected from the total number of networks that went through the learning process. In our study, let's assume five networks. Having received a window of results, we go to various modes of learning the network. Let's carry out learning using the user's neural network method and the method of multiple subsamples. The learning results allow to compare the architecture of each network and analyze the performance of learning the network on the learning, control and test samples. This value is characterized by the coefficient of determination (the closer to one, the better the model) 
and shows how this model approximates the data. The learning errors, learning algorithm, error functions and activation functions are indicated (Fig. 7).

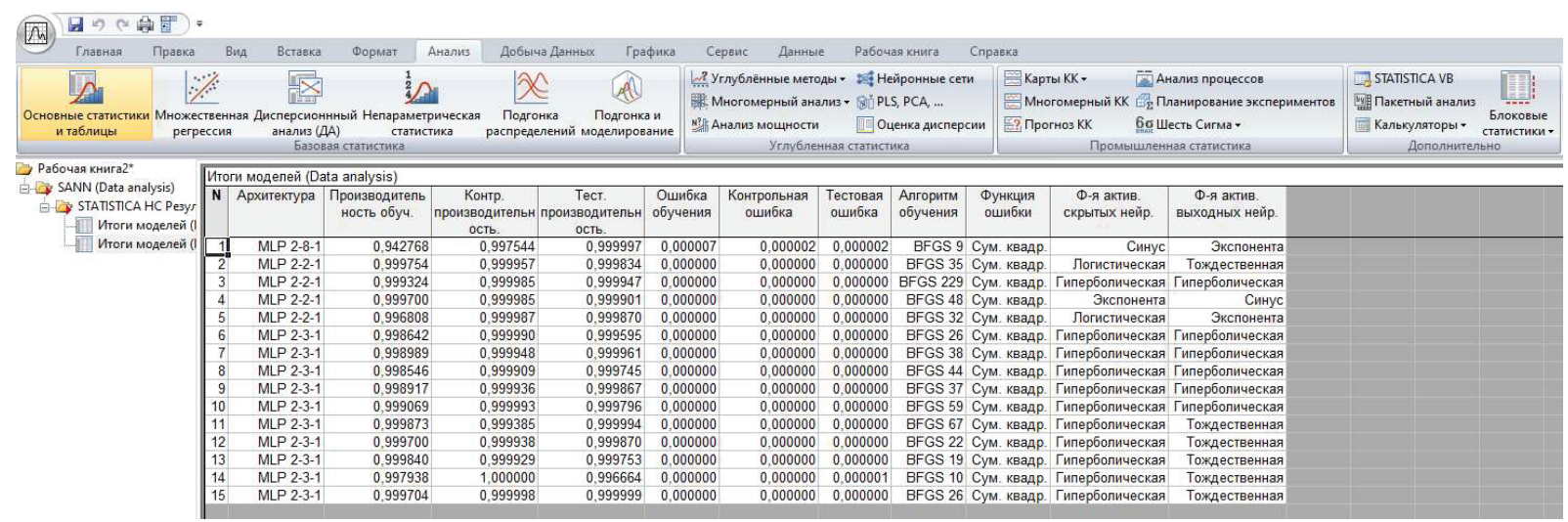

Fig. 7. Results of learning neural networks, c.u.

On the Graphs tab, using graphical analysis, let's determine the neural networks that have the most adequate behavior. Let's build a histogram of residuals for each individual network. Most of the data is concentrated in a small interval (Fig. 8).

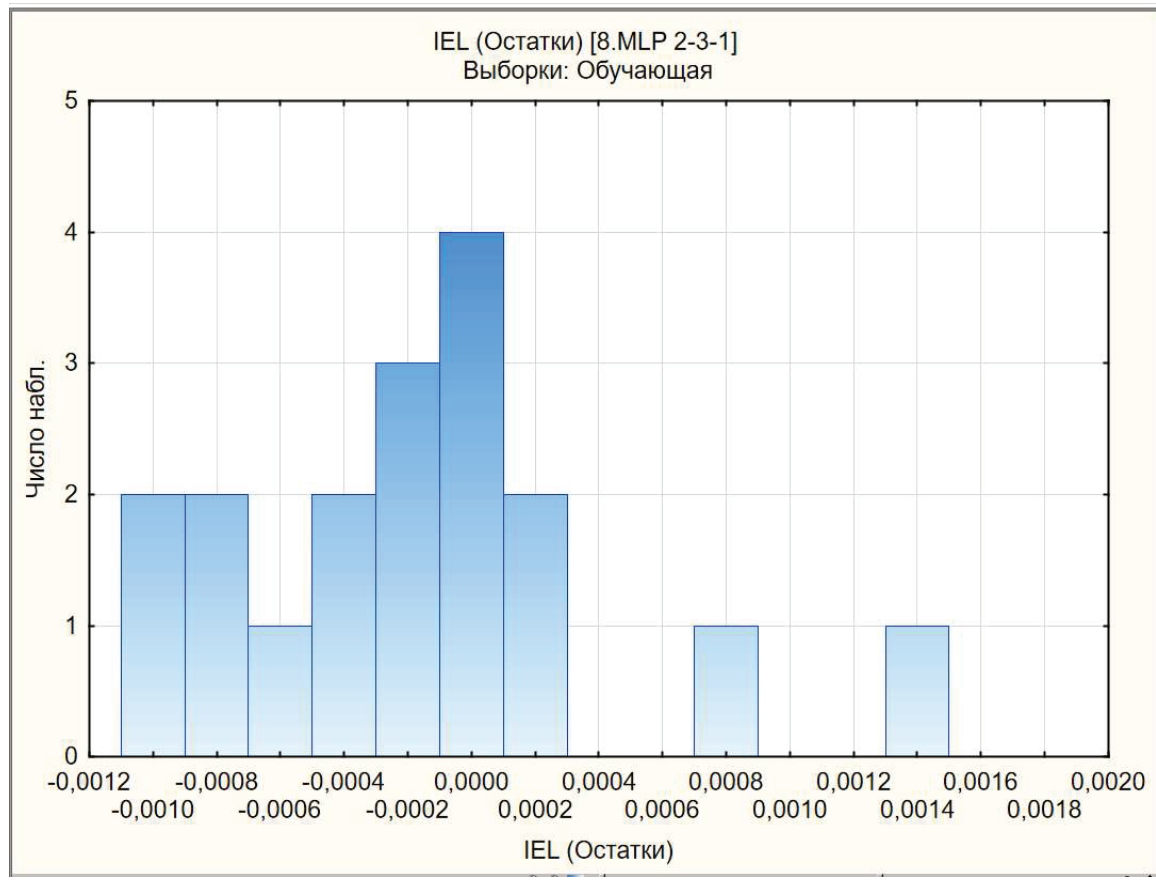

Fig. 8. Histogram of residuals for each individual network, c.u.

Let's build a scatter diagram of the target and initial values of each network. The graph shows all grids and the original $Y$ value. Ideally, all the original grid values are located on the line $Y$. The scatter diagram shows a small range of data spread (Fig. 9).

Let's build a response surface for $E L_{2}, E L_{3}$, and the initial value $I_{E L}$. The sigmoid S-shape reflects the dependence of the data without significant deviations of the points from the surface of the curve (Fig. 10).

The Analysis Summary tab provides weights, correlation coefficients, forecast statistics, and global and local sensitivity analyzes for each network (Fig. 11). The results of the global sensitivity analysis characterize the importance of the value of each variable. All networks showed the importance of indicators $E L_{2}, E L_{3}$ (Fig. 11). 


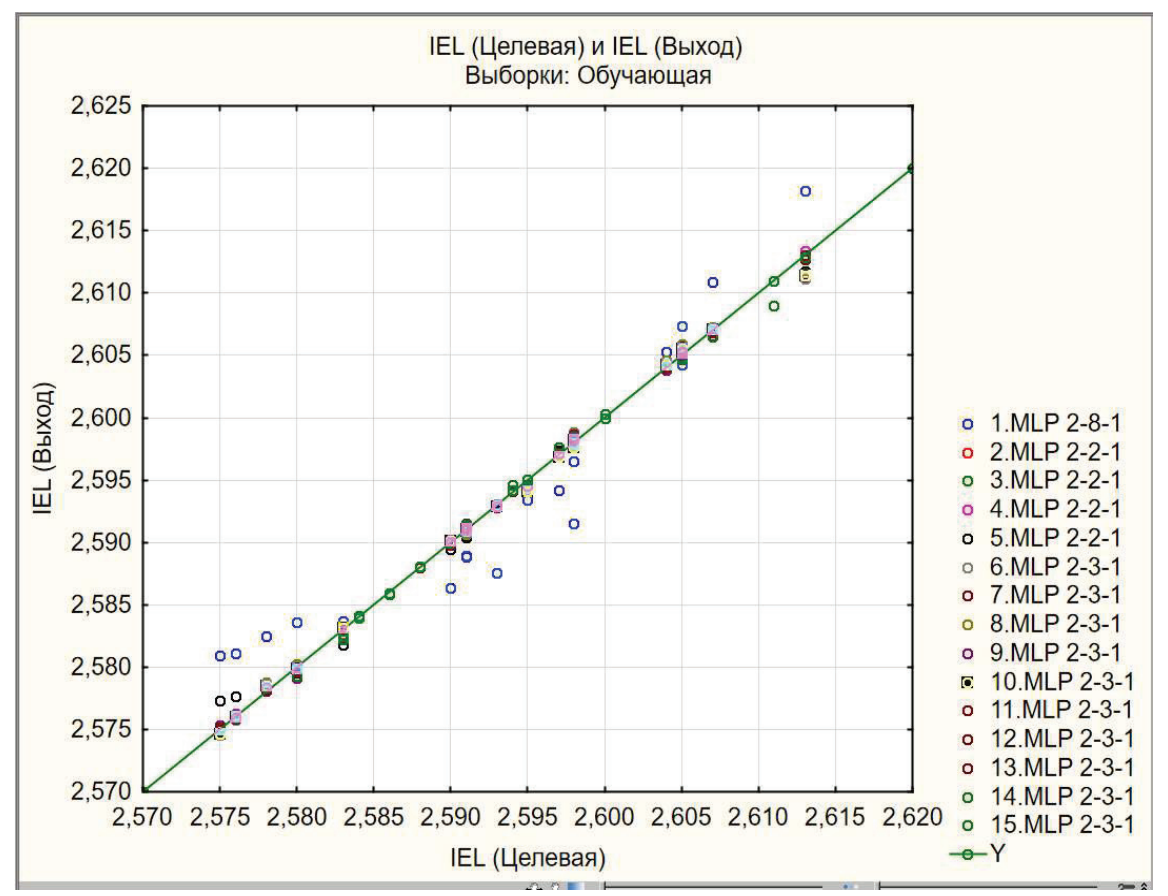

Fig. 9. Scatter diagram of target and initial values of networks, c.u.

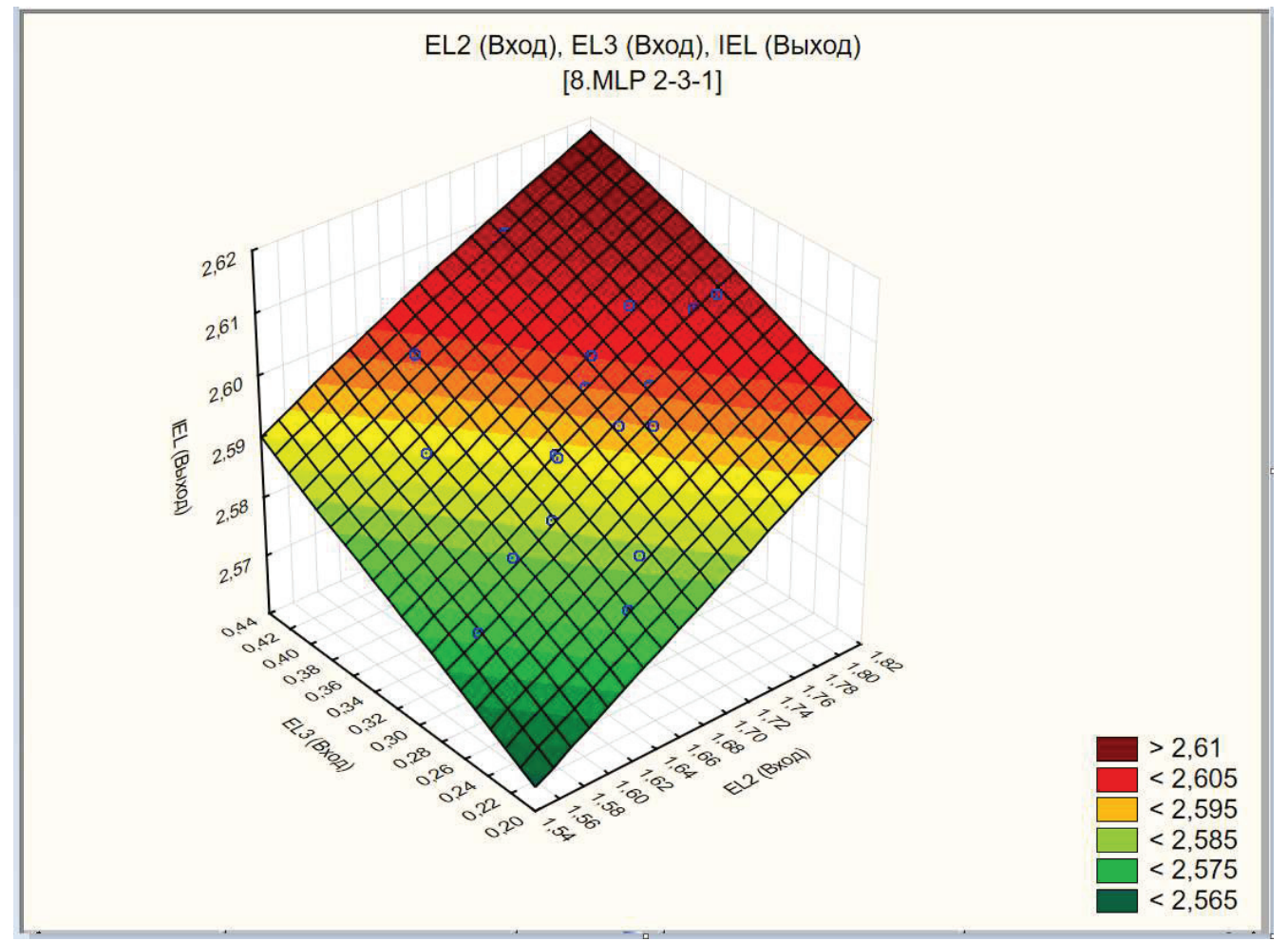

Fig. 10. The surface of the neural network response, c.u.

Having indicated the number of new observations that need to be predicted, let's enter the data and obtain the value for predicting each of the networks (Fig. 12).

For a detailed determination of the quality of the model, let's select one model with the highest performance per control sample. Let's evaluate the quality of the selected model 8MLP 2-3-1 for test sample, including absolute residuals in the calculation. The resulting data table is only for test observations (Fig. 13). 


\begin{tabular}{||l|r|r|}
\hline \multirow{2}{*}{ Сети } & \multicolumn{2}{|l}{ Чувствительность (Data analysis) } \\
\cline { 2 - 3 } & \multicolumn{1}{|c|}{$\mathrm{EL}_{2}$} & \multicolumn{1}{|c}{$\mathrm{EL}_{3}$} \\
\hline 1.MLр 2-8-1 & \multicolumn{1}{|c|}{7,349} & 1,8984 \\
\hline 2.MLP 2-2-1 & 1377,499 & 373,2679 \\
\hline 3.MLP 2-2-1 & 481,850 & 127,9374 \\
\hline 4.MLP 2-2-1 & 1119,334 & 304,4717 \\
\hline 5.MLP 2-2-1 & 94,651 & 27,2886 \\
\hline 6.MLP 2-3-1 & 249,250 & 65,8721 \\
\hline 7.MLP 2-3-1 & 332,691 & 85,6142 \\
\hline 8.MLP 2-3-1 & 235,248 & 62,0204 \\
\hline 9.MLP 2-3-1 & 285,649 & 76,9058 \\
\hline 10.MLP 2-3-1 & 347,725 & 93,3768 \\
\hline 11.MLP 2-3-1 & 2515,471 & 767,3191 \\
\hline 12.MLP 2-3-1 & 1131,673 & 306,0096 \\
\hline 13.MLP 2-3-1 & 1705,126 & 643,0726 \\
\hline 14.MLP 2-3-1 & 138,040 & 63,1119 \\
\hline 15.MLP 2-3-1 & 909,504 & 529,9037 \\
\hline Cреднеe & 728,737 & 235,2047 \\
\hline
\end{tabular}

Fig. 11. Global sensitivity analysis of neural networks, c.u.

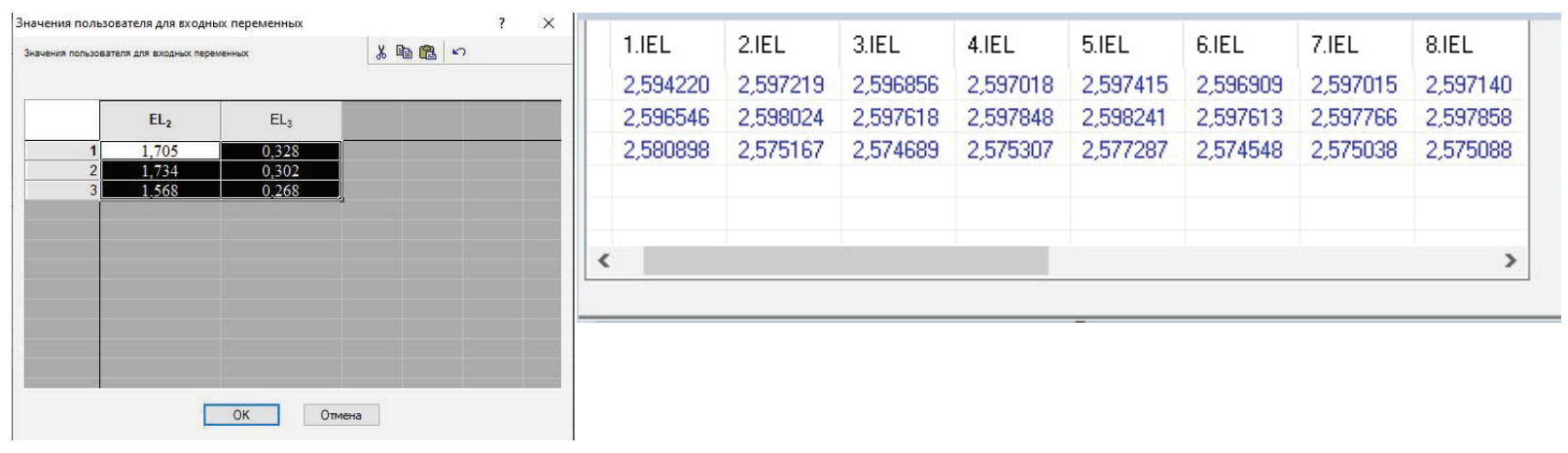

Fig. 12. Forecasting data on new observations, c.u.

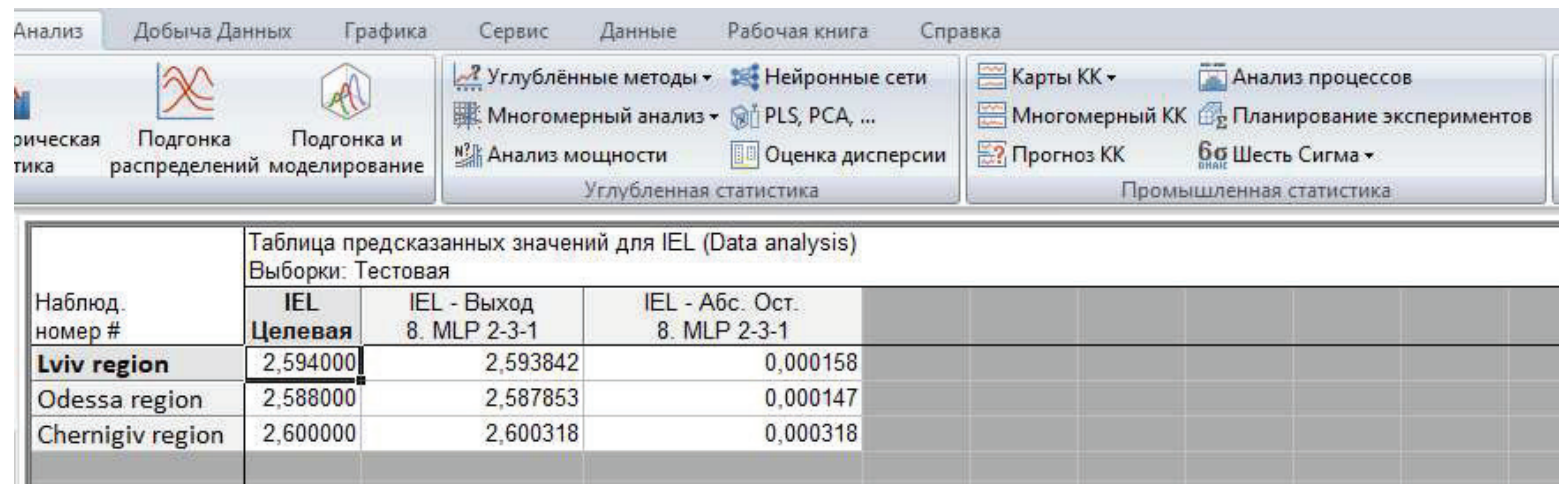

Fig. 13. Predicted values of the test sample, c. u.

To assess their quality and determine the relative error, it is necessary to introduce an additional variable MAPE, which will determine the relative value of the error. The average value of the relative error on the test set is $0.008 \%$, which indicates a good quality of the constructed model (Fig. 14).

The model is saved in PMML format in the STATISTICA system.

Thus, the analysis of the adequacy of the developed mathematical models of the influence of factors on the integral indicator of the level of land use of objects of the natural reserve fund of the regions using the neural network method made it possible to confirm the completeness and reliability of the established relationships based on low values of the relative error of the test sample. 


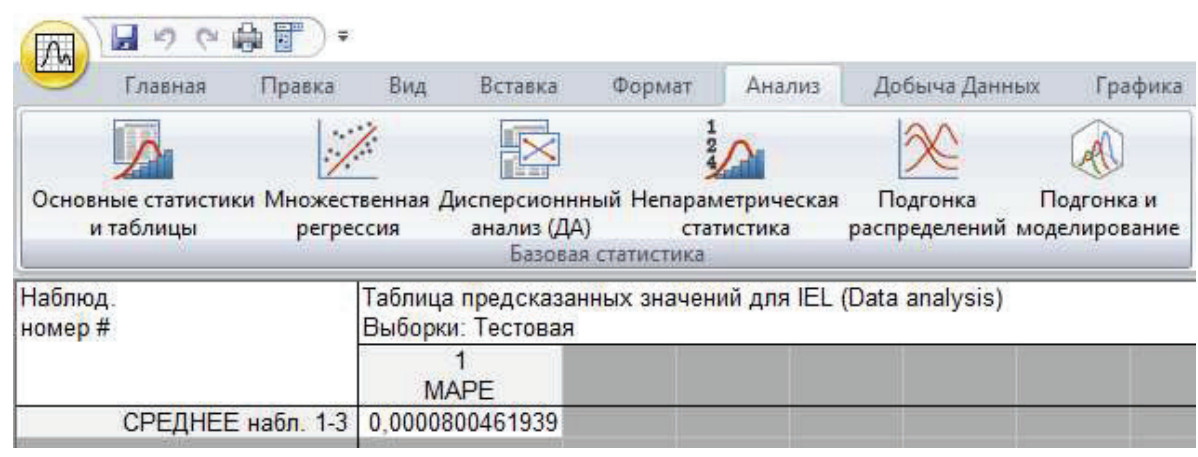

Fig. 14. Average value of the relative error on the test sample, c.u.

\section{Discussion}

So, the integral indicator of the level of land use of the objects of the natural reserve fund of the regions using the neural network method made it possible to determine the following:

- the results of mathematical modeling provide an opportunity to predict changes in the integral indicator of the level of land use of objects of the natural reserve fund of the regions, depending on the relevant factors;

- the results of mathematical modeling provide an opportunity to offer scientifically grounded recommendations for the development and implementation of monitoring of the formation of lands of objects of the natural reserve fund of the regions;

- the integral indicator is developed on the basis of the analysis and assessment of a set of factors that are defined as parameters for assessing the lands of the natural reserve fund;

- the analysis makes it possible to confirm the completeness and reliability of the established relationships based on low values of the relative error of the test sample.

The limitations of the study are that the results of the analysis reflect the actual methodology only for the national system of natural reserve fund due to the limited system of national legislative regulation.

The area of practical use of research results. Thus, the practical significance of the developed model for the formation of a methodology for assessing the processes of using lands of the natural reserve fund has been determined.

Innovative technological product: an integral model for assessing the lands of the natural reserve fund.

Scope of application of an innovative technological product. This technique makes it possible to increase the efficiency and rationalize the processes of using the lands of the natural reserve fund in order to protect them and ensure integrated functioning.

\section{Conclusions}

As a result of mathematical modeling, it was found that changes in the system factor for the development of information and analytical support for the formation and implementation of monitoring of lands of objects of the natural reserve fund of regions $\left(E L_{2}\right)$ by $78.7 \%$ causes changes in the integral indicator of the level of land use of objects of the natural reserve fund of regions $\left(I_{E L}\right)$. This indicates a high level of influence of information and analytical support and requires the development of appropriate scientifically grounded measures for their growth. A change in the systemic factor of the level of rational use and protection of natural resources, influencing the development of monitoring the formation of lands of objects of the natural reserve fund of regions $\left(E L_{3}\right)$ by $45.9 \%$, causes changes in the integral indicator of the level of use of lands of objects of the natural reserve fund of regions $\left(I_{E L}\right)$. This is a profound meaning, indicating the need to take action to increase the direction of implementation of the rational use and protection of natural resources. The results of mathematical modeling provide an opportunity to predict changes in the integral indicator of the level of land use in the objects of the natural reserve fund of the regions, depending on the relevant factors and to offer scientifically grounded recommendations for the development and implementation of monitoring of the formation of lands of the objects of the natural reserve fund of the regions. 
To confirm the adequacy of the established links between the integral indicator of the level of land use of objects of the natural reserve fund of regions and factors, the method of neural networks is used based on the STATISTICA Neural Networks software package. Neural networks allow to model and reproduce complex nonlinear dependencies, while simultaneously requiring a lower level of knowledge than when using traditional statistical methods. The analysis of the adequacy of the developed mathematical models of the influence of factors on the integral indicator of the level of land use of objects of the natural reserve fund of the regions using the neural network method made it possible to confirm the completeness and reliability of the established relationships based on low values of the relative error of the test sample.

\section{References}

[1] Miroshnychenko, O. V., Artamonov, V. A. (2013). Instytutsiini problemy stvorennia ta rozvytku obiektiv pryrodno-zapovidnoho fondu Ukrainy. Vseukr. ekol. liha. Kyiv: Aspekt-Polihraf, 6, 5-8.

[2] Kovyazin, V. F., Demidova, P. M., Lan Anh, D. T., Hung, D. V., Quyet, N. V. (2020). Monitoring of Forest Land Cover Change in Binh Chau - Phuoc Buu Nature Reserve in Vietnam Using Remote Sensing Methods and GIS techniques. IOP Conference Series: Earth and Environmental Science, 507, 012014. doi: http://doi.org/10.1088/1755-1315/507/1/012014

[3] Kalbarczyk, E., Kalbarczyk, R., Kasprzak, K., Krajewski, P., Raszka, B. (2016). National Parks in Poland. Bielsko-Biała: Wydawnictwo Dragon.

[4] Chornyi, M. H. (1993). Pro osoblyvosti ukrainskykh zapovidnykiv ta stratehiiu zapovidnoi spravy v Ukraini. Pidsumky 70-richnoi diialnosti Kanivskoho zapovidnyka ta perspektyvy rozvytku zapovidnoi spravy v Ukraini. Kaniv, 20-22.

[5] Vasyliuk, O., Kostiushyn, V., Kolomytsev, H. (2011). Novi pidkhody do rozbudovy natsionalnoi ekomerezhi Ukrainy Pryrodno-resursnyi potentsial zbalansovanoho (staloho) rozvytku Ukrainy. Kyiv: Tsentr ekolohichnoi osvity ta informatsii, 2.

[6] Mamonov, K. A., Hrek, M. O., Meteshkin, K. O. (2017). Rozrobka steikkholderno-oriientovanoho pidkhodu do otsinky vplyvu mistobudivnykh faktoriv na vykorystannia zemel. Visnyk Khmelnytskoho natsionalnoho universytetu. Tekhnichni nauky, 3 (249), 160-164.

[7] Mamonov, K. A., Nesterenko, S. H., Viatkin, K. I. (2016). HIS-zabezpechennia u ratsionalnomu vykorystanni zemelnykh resursiv miskoi zabudovy. Naukovyi visnyk budivnytstva, 86 (4), 323.

[8] Leconte, J., Forget, F., Charnay, B., Wordsworth, R., Pottier, A. (2013). Increased insolation threshold for runaway greenhouse processes on Earth-like planets. Nature, 504 (7479), 268-271. doi: http://doi.org/10.1038/nature12827

[9] Korniiets, A. V., Savenko, V. Ya. (2017). Metodychni rekomendatsii shchodo realizatsii metodu otsinky heoekolohichnoho stanu vykorystannia zemel naselennykh punktiv. Avtomobilni dorohy i dorozhnie budivnytstvo, 103, 5-10.

[10] Korniiets, A. V., Mamonov, K. A. (2017). Suchasni aspekty formuvannia heoekolohchnoho monitorynhu vykorystannia zemel rehionu. Komunalne hospodarstvo mist. Seriia Tekhnichni nauky ta arkhitektura, 137, 31-33.

[11] Fung, I., Doney, S., Lindsay, K., John, J.: Evolution of carbon sinks in a changing climate. Proc. Nat. Acad. Sci. U. S. Am. 102(32), 11201-11206 (2005)

[12] Butko, M., Zelenskyi, S., Akymenko, O. (2005). Suchasna problematyka otsinky investytsiinoi pryvablyvosti rehionu». Ekonomika Ukrainy, 11, 30-35. 